\title{
UP-233 前立腺癌治療後に併発した重複癌
}

\author{
東京都立墨東病院 泌尿器科 ${ }^{1}$ \\ 二万律治" 今尾 貞夫" 深澤 立”
}

【目的】前立腺癌は他臟器に癌を合併する頻度が高い。今回我 々は前立腺癌治療後に併発した症例の治療法之併発癌との関連の 有無を検討した。【対照と方法】1986年から1999年迄14年間に 当院で初回治療を行った前立腺癌270例を対照とした。これらの うちWarren \& Gatesの定義を満足する症例を重複癌とし, さら に前立腺癌治療開始1年以降に他臟器癌を併発した症例の治療法 について検討した【【結果】前立腺癌患者のうち49例（18.1\%） が重複癌であり5例は3重複癌であった。前立腺癌の治療後に他臓 器癌を併発した症例は14例であった。併発した他臟器癌は胃癌が 6例之肺癌, 食道癌, 大腸癌, 肝臟癌, 腎癌, 皮痛癌, 白血病抒 よび綎隔腺癌が各 1 例であった.前立腺癌の治療開始から併発癌の 発見までの間隔は 1 年から 8 年平均 4.3 年であった。手術以外には 放射線治療5例（併用を含屯），estramustine phosphate sodium投 与9例，LH-RHアナログ5例であった，前立腺癌270例のうち，放 射線治療を受けた症例は88例，LH-RHアナログ治療は74例， estramustine phosphate sodium投与例は117例で3治療の有無によ る併発癌の発生頻度は $\chi 2$ 検定では有意差はなかった。【結論】 今回の検討では前立腺癌治療による誘発癌の可能性は否定的であ った。

\section{前立腺癌 重複癌 治療後}

\section{UP-235 T1c前立腺癌の再生検による治療法の選択}

\author{
東芝林間病院 泌尿器科 11 \\ 菅野ひとみ"長田裕”太田純一"”賢訓久" \\ 土屋ふとじ \\ 【目的】T1c前立腺癌の発見率力增加するに伴い、臨床的に重要 \\ でない癌に対する手術適応の可否が新たな問題となってきた。我 \\ 々は定期的な再生検結果上患者本人の意思に従い治療法を選択し \\ ており、その治潦経過についてretrospectiveに検討した。【対象、 \\ 方法】1995年 1 月から2000年6月に当院で診断したT1c前立腺癌患 \\ 者39例。(1)再生検群21例 (2) 手術群10例 (3) その他8例に分けて \\ 検討。【結果】39例全例でTAB療法又はLHRHアナログ単独投 \\ 与。(1)21例に1 3 回の再生検を行い、16例がGrade 3 (G3)、 \\ 癌細胞残存の認められた 5 例中 2 例で全摘出術施行、3 例で内分 \\ 泌療法続行。(2)10例でネオアジュバント療法後前立腺全摘出術 \\ 施行。全摘出術施行した計12例中 4 例は G $3 、 3$ 例はcap + 又は \\ $\mathrm{pn}+$ の進行癌であった。(3)生検予定の 2 例、転居など 5 例では \\ 組織未確認。尿閉にてTAB後TURPが1例、組織はG 3 であった。 \\ 【結論】結局内分泌療法後組織確認のできた 32 例において、21 \\ 例は治療後viable cancer cells を認めなかった（G 3)。少なくと \\ もT1cの過半数は手術療法を急ぐ必要はない一方、4 分の 1 には \\ 臨床的に重要な癌、さらに約 1 割には進行癌が存在し、両者の見 \\ 極汭さらに長期の検討が必要と思わ狆た。
}

T1c前立腺癌 再生検 組織学的治療効果判定

\section{UP-234 無治療経過観察した前立腺癌症例の臨床的 検討}

\author{
関西医大附属洛西ニュータゥン病院 泌尿器科 1 \\ 西淀病院 泌尿器科 ${ }^{2)}$ 関西医科大学 泌尿器科 ${ }^{3)}$ \\ 河 源”日浦 義仁" 岡田 日佳" ${ }^{3}$ 室田 卓之"” \\ 川喜田 睦司 ${ }^{3 /}$ 松田 公志 $^{31}$
}

【目的、方法】1995年以降、系統的前立腺針生検にて前立腺癌と 診断した症例のうち、無治療かつ定期的な経過観察をおこなった 25例を対象とし、retrospectiveな検討をおこなった。時間の経過 と血清PSA值の上昇が、統計学的に有意に相関したものをPSA上 昇群とし、非上䀘群との差異を検討した。【結果】観察期間中央 値22.4 万 $(6.0 \sim 46.8$ 个月)、年齢中央值70.0歳 $(54 \sim 87$ 歳)、生 検時平均PSA $12.4 \mathrm{ng} / \mathrm{ml}(0.6 \sim 65)$ 、Gleason score平均值 3.3 $(2 \sim 8)$ 、病期 T $1 \mathrm{c}: 13$ 例、B1：12例、B2：1例であった。PSA上 昇群は4例（16\%）あり、すべて病期B1であった。うち 1 例に内 分泌療法が施行された。上昇群之非上昇群の間に、生検時の年齢 で有意差がみられた（ $\mathrm{p}=0.025 ） 。$ 再生検は9例に施行されたが、 うち6例（67\%）には癌は検出されなかった。非上昇群のうち1例 （病期B1）で、画像診断上明らかな病勢の進行が認められたため、 根治手術を施行した。【結論】Tlc癌で、Gleason scoreが低く、 病巣が微少である場合は、無治療とすることも充分選択しうる才 プションと考えられた。初期診断時に、以後のPSA上昇の有無を 判断しうるパラメーターは見出されなかった。

前立腺癌 無治療経過観察 PSA

\section{UP-236 当院における前立腺癌患者の治療の選択状}

\section{大阪市立十三市民病院 泌尿器科" 河西クリニック 大阪市立弘済院附属病院 ${ }^{3)}$ 大阪市立大学}

栘田 周佳 "西阪 誠泰”安本 亮二" 河西 宏信 河野 学 ${ }^{3 !}$ 田中 智章 ${ }^{4 !}$ 甲野 拓朗 ${ }^{4}$ 岸本 武利 ${ }^{4}$

【目的】大阪市立十三市民病院で経験した前立腺癌患者の手術選 択状況について検討した。【対象】対象は1995年1月から2000年 9月までに大阪市立十三市民病院を受診し病理組織学的に前立腺 癌之診断された 59 例で,年齢は57-88歳, 平均 73.7葴であった。

【結果】臨床病期別はA2か32例,Bが31例,Cが8例,Dが16例で, Grade は高分化癌が20例,中分化癌が28例,低分化癌が10例, 未分化癌が 1 例であった.Dはすべてに内分泌療法が施行された.当院で手術適 応と考えたB,C,特にTNM分類でT3aNOM0までの症例は36例で,年 齢は57-88歳, 平均72.2歳であった.71歳まで手術適応年齢之設定 した場合21例(58.3\%)となり,16例(44.4\%)に手術が施行された。 方,患者の社会性，家族性から，実際72歳以上の患者でむ15例中5例 (33\%)で手術療法が施行された。手術療法の患者年齢は57-79歳, 平均68.2歳で,放射線療法，内分泌療法の患者年歯命は64-88歳,平均 76.8歳であった。【結語】当院では手術療法の選択性については 明らかに年齢構成が低い患者に反映されていたが,その反面72歳 以上の $33 \%$ の患者が手術を受け入れており，患者の社会性,家族 性の要求にも考慮される必要性が示唆された。

前立腺癌 治療選択 年齢 